\title{
Standardization of Suitable Drying Methods for Storing Groundnut and Sesame Seeds
}

\author{
V. Vijaya Geetha ${ }^{1 *}$ and M. Bhaskaran ${ }^{2}$ \\ ${ }^{1}$ Oilseeds Research Station, TNAU, Tindivanam, Tamil Nadu, India \\ ${ }^{2}$ RRS, TNAU, Tirur, Tamil Nadu, India \\ *Corresponding author
}

\begin{abstract}
A B S T R A C T
India is one of the important oilseeds grower and importer of edible oils. India stands fourth in oil production next to USA, China \& Brazil. An oilseed crop like groundnut, sesame and sunflower have been the backbone of several agricultural economies and plays a vital role in agricultural industries and trade throughout the world. Drying of seeds plays a major role in maintaining the quality of seeds. Drying of Rabi harvested Groundnut as well as Sesame seeds is a very big challenge as far as Tindivanam is concerned. Since the seeds were exposed to very hot sun, it leads to cracking of seed coat which in turn leads to poor germination. Hence, to avoid exposing the groundnut as well as sesame seeds to very high temperature, the seed drying method is to be standardized for each seeds. To find the suitable seed drying methods for Groundnut TMV 13 and Sesame TMV 7, the seeds of Groundnut TMV 13 and Sesame TMV 7 were subjected to three methods of drying viz., Sun drying (Completely under sun), Shade drying (under tree shade)and Partial shade drying (morning under shade and evening under sun). The pods were dried to the uniform moisture content of $9 \%$ and packed in cloth bags and stored under ambient condition for ten month at Oilseeds Research Station, Tindivanam. The seeds were evaluated for Moisture content, Germination percentage, Shoot length, Root length, Vigour index, Dry Matter production, Electrical Conductivity and Field Emergence at monthly interval. Seed storage studies revealed that the decrease in germination was faster in seeds groundnut seeds. The germination per cent decreased from 95.7 to 49.3 per cent during 10 months of storage. The vigour parameters like root and shoot length, dry matter production of seedlings, vigour index values and field emergence per cent decreased with increase in storage period. The seeds dried under shade registered maximum germination percent (79.4 percent), vigour index (2098), Dry matter Production $(2.89 \mathrm{mg} / \mathrm{seedling})$, Electrical Conductivity $0.312 \mathrm{ds} / \mathrm{m}$ and Field emergence (72.5 percent). Similar trend has been observed for Sesame seeds also. In sesame, Minimum fluctuation in seed moisture content was observed in sesame seeds under different drying methods. The shade dried sesame seeds with initial moisture content of 8 per cent, stored in cloth bag recorded the highest germination ( 83.8 per cent), longest root and shoot length, maximum dry matter accumulation $(34.4 \mathrm{mg})$, maximum vigour index (1219) and field emergence (80.8 per cent)at end of tenth month of storage.
\end{abstract}

Keywords

\section{Introduction}

Groundnut [Arachis hypogea (L.)] is an important oilseeds crop and it has vital role in the diet of rurals and urbans. Groundnut also known as peanut is considered as one of the most important oilseed crops and grown throughout the world. Sesame (Sesamum indicum) commonly known as til (Hindi) is an ancient oilseed crop of India. It is called as 'queen' of oilseeds by virtue of its excellent oil quality (Vijaya Kumar et al., 2014). Seed is being a biological or living entity, deterioration in is inevitable and inexorable. 
Deterioration occurs with advance in ageing, during storage, number of biotic and abiotic factors influences the storage of seeds (Kumar et al., 2014). Maintenance of quality of seed during storage is a big menace due its quick viability loss. The extent of seed deterioration depends on many factors which includes species, seed containers, seed treatment, storage environment, duration of storage period and initial quality of seeds. Different chemicals can be used for protection of seeds. Groundnut being a poor storer, Storing of groundnut seeds after harvest till the next cropping season without deteriorating the quality of seed for successful and quality seed production. The loss of seed viability is more severe in groundnut produced during Rabi season and harvested in the summer season and about more than fifty per cent viability could be lost within 4-5 months of storage.

Seed storage in groundnut is an imperative, seasonal demand, dormancy, specificity of planting time, necessity of carry over and need of buffer seed stock. Seeds with high oil content appear to lose their germination and vigour in a short time despite the precaution taken during harvesting and drying. High temperature and high relative humidity cause severe and rapid deterioration of viability and vigour of groundnut seeds. The environmental conditions that exist during the growth period and harvesting time affects the seed quality and storability. Thus, the environment / provenance plays a major role in determining the seed storability and quality.

\section{Materials and Methods}

Freshly harvested seeds of groundnut TMV 13 and Sesame TMV 7 obtained from Oilseeds Research Station, Tindivanam formed the base material for the study. The seeds were subjected to the following treatments

$\mathrm{T}_{1}-$ Sun drying (Morning and Evening)
$\mathrm{T}_{2}$ - Shade drying (Completely under shade)

$\mathrm{T}_{3}-$ Partial Shade drying (Partially under tree shade)

After drying, the pods were dried to the uniform moisture content of $8 \%$ and packed in cloth bags and stored under ambient condition for ten month. The seeds were evaluated at bimonthly interval for first six months and monthly interval from sixth months onwards for its quality parameters viz., Germination Percentage (ISTA,1999), Root length $(\mathrm{cm})$, Shoot length $(\mathrm{cm})$, Dry matter production (g 10 seedling $^{-1}$ ), Vigour index (Abdul-Baki and Anderson, 1973), Electrical Conductivity $\left(\mathrm{dsm}^{-1}\right)$ (Presley, 1958), Oil Content \% (Sadasivam and Manickam, 1995) and Field Emergence (\%).

\section{Results and Discussion}

\section{Groundnut}

Fluctuation and significant difference in moisture content was observed due to seed treatment and Period of storage (Table.1). Among the various seed treatments, the Seeds dried under shade registered the minimum fluctuation in moisture content (8.4 to 8.65 per cent). The decline in germination from 95 per cent to 47 per cent was observed during storage period (Table. 1). The vigour parameters like root and shoot length, dry matter production and vigour index values (Table. 2) were decreased with advancement of storage period, irrespective of drying methods and decrease in these parameters was rather slow in shade dried seeds. Dry matter production due to treatments and period of storage was significant (Table.2). Among the various drying methods, Shade dried seeds registered the maximum dry matter $(2.89 \mathrm{~g})$ followed by Partial shade drying $(2.71 \mathrm{~g})$. The electrical conductivity in the seed leachate increased with increase in storage period from 0.126 to $0.614 \mathrm{dSm}^{-1}$ (Table.3). Field 
emergence potential of the shade dried seed was maximum (72.2\%) compared to Sun dried (67.8\%) and Partial Shade dried (69.9 $\%$ ) (Table-3).

\section{Sesame}

In the present study a significant difference was noticed between drying methods and period of storage. Here the moisture fluctuations occurs due to very hot temperature after six months of storage (Table.4). Decline in germination is the last physiological phenomenon in the process of ageing. In the present study, reduction in germination was noticed in seeds produced under rainfed as well as irrigated condition over a period of storage.

The germination per cent decreased from 88 to 82 per cent in shade dried seed after 10 months of storage and 87 to 78 per cent in sun seed. (Table.4). Vigour is usually characterized by the weight of the seedlings after a period of growth and it is essentially a physiological phenomenon influenced by the reserve metabolites, enzyme activities and growth regulators. Vigour index value, which is the totality of germination and seedling growth has been regarded as a good index to measure the vigour of seeds.

Loss of vigour precedes loss of viability. In the present study, the vigour index value decreased with increase in storage period from 1502 to 1076 at the end of 10 months period and decrease in vigour index value was faster in sun dried seed compared to shade dried seeds. (Table.5)Dry matter production due to drying methods and period of storage was significant (Table.5).

Shade drying method registered the maximum dry matter (36.73 $\mathrm{mg}$ ) compared to control (34.92 mg). The initial electrical conductivity was higher in shade dried seed than in sun dried seed. This clearly showed that the sun dried seed might have experienced a slight injury to membrane due to higher temperature prevailed during drying. The increase in electrical conductivity with the advancement of storage period (Table.6).

The field emergence potential is considered to be an important parameter for assessing the potentiality of seeds to perform better under field conditions. The present study revealed that, as the storage period advanced field emergence potential reduced gradually, irrespective of seed drying methods. Among the different drying methods, shade dried seeds registered maximum seed field emergence $(82.3 \%)$ compared to sundried (79.8\%) (Table-6).

The moisture content of the seed plays a prime role in determination of storability of any seed and it increases with advances in storage period. The moisture content at which seeds were stored had a significant effect on seed longevity has been reported by many authors (Ellis et al., 1990; Nakamura, 1975; Zheng, 1994). The decline in germination during storage may be due to depletion of food reserves, decline in synthetic activity as reported by Heydecker (1972) and Roberts (1972) or may be due to the physiological ageing process.

The superiority of shade dried seeds in maintaining higher germination (79.4 \%) compared to Sun drying (75.9 per cent) in storage was due to safe drying method which protect the seed coat from cracking their by maintaining its germination percent. Similar result was obtained by Shakuntala (2009) in sunflower. Seedling length and dry matter production of the seedling are the manifestations of the physiological efficiency of the germinating seeds which depends on the seed vigour. 
Table.1 Effect of drying methods on Moisture Content and Germination Percentage in Groundnut TMV 13

\begin{tabular}{|c|c|c|c|c|c|c|c|c|c|c|c|c|c|c|c|c|c|c|}
\hline \multicolumn{10}{|c|}{ Moisture Content } & \multicolumn{9}{|c|}{ Germination Percentage } \\
\hline Treatment & P0 & $\mathbf{P 2}$ & $\mathbf{P 4}$ & P6 & P7 & P8 & P9 & P10 & Mean & P0 & $\mathbf{P 2}$ & P4 & P6 & P7 & P8 & P9 & P10 & Mean \\
\hline $\begin{array}{l}\text { Sun } \\
\text { drying }\end{array}$ & 8.1 & 8.6 & 8.8 & 8.7 & 8.4 & 8.1 & 8.1 & 8.0 & 8.35 & 95 & 92 & 89 & 85 & 74 & 66 & 59 & 47 & 75.9 \\
\hline $\begin{array}{l}\text { Shade } \\
\text { drying }\end{array}$ & 8.4 & 8.8 & 9.1 & 9.0 & 8.8 & 8.4 & 8.3 & 8.2 & 8.63 & 97 & 94 & 91 & 89 & 78 & 70 & 63 & 53 & 79.4 \\
\hline $\begin{array}{l}\text { Partial } \\
\text { shade } \\
\text { drying }\end{array}$ & 8.3 & 8.6 & 8.9 & 8.7 & 8.5 & 8.3 & 8.2 & 8.1 & 8.45 & 96 & 93 & 90 & 87 & 76 & 68 & 61 & 48 & 77.4 \\
\hline Mean & 8.27 & 8.67 & 8.93 & 8.80 & 8.57 & 8.27 & 8.20 & 8.10 & 8.48 & 96.0 & 93.0 & 90.0 & 87.0 & 76.0 & 68.0 & 61.0 & 49.3 & 77.5 \\
\hline & $\mathbf{P}$ & & $\mathbf{T}$ & & PxT & & & & & $\mathbf{P}$ & & $\mathbf{T}$ & & PxT & & & & \\
\hline & 0.041 & & 0.025 & & 0.073 & & & & & 0.499 & & 0.305 & & 0.864 & & & & \\
\hline $\mathrm{CD}(0.05)$ & 0.084 & & 0.051 & & 0.145 & & & & & 0.999 & & 0.612 & & 1.730 & & & & \\
\hline
\end{tabular}

Table.2 Effect of drying methods on Vigour index and Dry Matter Production (mg 10 seedling $^{-1}$ ) in Groundnut TMV 13

\begin{tabular}{|c|c|c|c|c|c|c|c|c|c|c|c|c|c|c|c|c|c|c|}
\hline \multicolumn{10}{|c|}{ Vigour Index } & \multicolumn{9}{|c|}{ Dry Matter Production (mg 10 seedling $^{-1}$ ) } \\
\hline Treatment & P0 & $\mathbf{P 2}$ & $\mathbf{P 4}$ & P6 & P7 & P8 & P9 & P10 & Mean & P0 & $\mathbf{P 2}$ & P4 & P6 & P7 & P8 & P9 & P10 & Mean \\
\hline Sun drying & 3306 & 2972 & 2537 & 2193 & 1769 & 1379 & 1109 & 672 & 1890 & 3.31 & 3.25 & 3.13 & 3.00 & 2.69 & 2.36 & 2.18 & 1.79 & 2.71 \\
\hline $\begin{array}{l}\text { Shade } \\
\text { drying }\end{array}$ & 3434 & 3093 & 2757 & 2412 & 2020 & 1589 & 1273 & 901 & 2098 & 3.42 & 3.36 & 3.22 & 3.10 & 2.91 & 2.69 & 2.35 & 2.05 & 2.89 \\
\hline $\begin{array}{l}\text { Partial } \\
\text { shade }\end{array}$ & 3379 & 3032 & 2691 & 2349 & 1832 & 1476 & 1183 & 763 & 1990 & 3.36 & 3.28 & 3.16 & 3.06 & 2.81 & 2.48 & 2.25 & 1.88 & 2.79 \\
\hline Mean & 3373 & 3032 & 2661 & 2317 & 1872 & 1480 & 1187 & 776 & 1992 & 3.36 & 3.30 & 3.17 & 3.05 & 2.80 & 2.51 & 2.26 & 1.91 & 2.80 \\
\hline & $\mathbf{P}$ & & $\mathbf{T}$ & & PxT & & & & & $\mathbf{P}$ & & $\mathbf{T}$ & & PxT & & & & \\
\hline & 13.790 & & 8.445 & & 23.886 & & & & & 0.018 & & 0.011 & & 0.031 & & & & \\
\hline $\mathrm{CD}(0.05)$ & 27.582 & & 16.891 & & 47.774 & & & & & 0.037 & & 0.023 & & 0.064 & & & & \\
\hline
\end{tabular}


Table.3 Effect of drying methods on Electrical Conductivity $\left(\mathrm{dSm}^{-1}\right)$ and Field Emergence Percentage in Groundnut TMV 13

\begin{tabular}{|c|c|c|c|c|c|c|c|c|c|c|c|c|c|c|c|c|c|c|}
\hline \multicolumn{10}{|c|}{ Electrical Conductivity $\left(\mathrm{dSm}^{-1}\right)$} & \multicolumn{9}{|c|}{ Field Emergence Percentage } \\
\hline Treatment & P0 & $\mathbf{P 2}$ & P4 & P6 & P7 & P8 & P9 & P10 & Mean & $\mathbf{P 0}$ & $\mathbf{P 2}$ & P4 & P6 & P7 & P8 & P9 & P10 & Mean \\
\hline $\begin{array}{l}\text { Sun } \\
\text { drying }\end{array}$ & 0.127 & 0.159 & 0.196 & 0.237 & 0.303 & 0.45 & 0.52 & 0.635 & 0.328 & 95 & 92 & 87 & 80 & 74 & 56 & 40 & 18 & 67.8 \\
\hline $\begin{array}{l}\text { Shade } \\
\text { drying }\end{array}$ & 0.125 & 0.153 & 0.193 & 0.225 & 0.294 & 0.432 & 0.486 & 0.587 & 0.312 & 96 & 94 & 90 & 84 & 78 & 61 & 48 & 29 & 72.5 \\
\hline $\begin{array}{l}\text { Partial } \\
\text { shade }\end{array}$ & 0.126 & 0.155 & 0.195 & 0.228 & 0.298 & 0.396 & 0.498 & 0.62 & 0.315 & 95 & 93 & 89 & 81 & 76 & 58 & 42 & 25 & 69.9 \\
\hline Mean & 0.126 & 0.156 & 0.195 & 0.230 & 0.298 & 0.426 & 0.501 & 0.614 & 0.318 & 95.3 & 93.0 & 88.7 & 81.7 & 76.0 & 58.3 & 43.3 & 24.0 & 70.0 \\
\hline & $\mathbf{P}$ & & $\mathbf{T}$ & & PxT & & & & & $\mathbf{P}$ & & $\mathbf{T}$ & & PxT & & & & \\
\hline & 0.003 & & 0.002 & & 0.007 & & & & & 0.771 & & 0.473 & & 1.335 & & & & \\
\hline $\operatorname{CD}(0.05)$ & 0.008 & & 0.005 & & 0.014 & & & & & 1.543 & & 0.945 & & 2.672 & & & & \\
\hline
\end{tabular}

Table.4 Effect of drying methods on Moisture Content and Germination Percentage in Sesame TMV 7

\begin{tabular}{|c|c|c|c|c|c|c|c|c|c|c|c|c|c|c|}
\hline \multicolumn{8}{|c|}{ Moisture Content } & \multicolumn{7}{|c|}{ Germination Percentage } \\
\hline Treatment & P0 & $\mathbf{P 2}$ & P4 & P6 & P8 & P10 & Mean & P0 & $\mathbf{P 2}$ & P4 & P6 & P8 & P10 & Mean \\
\hline Sun drying & 8.0 & 8.1 & 8.3 & 8.5 & 8.2 & 8.1 & 8.20 & 87 & 85 & 83 & 82 & 80 & 78 & 82.5 \\
\hline Shade drying & 8.1 & 8.2 & 8.4 & 8.6 & 8.3 & 8.1 & 8.28 & 88 & 87 & 85 & 84 & 83 & 82 & 84.8 \\
\hline Partial shade drying & 8.0 & 8.1 & 8.2 & 8.5 & 8.3 & 8.2 & 8.22 & 87 & 86 & 84 & 83 & 82 & 80 & 83.7 \\
\hline & $\mathbf{P}$ & & $\mathbf{T}$ & & PxT & & & $\mathbf{P}$ & & $\mathbf{T}$ & & PxT & & \\
\hline & 0.027 & & 0.020 & & 0.048 & & & 0.542 & & 0.383 & & 0.942 & & \\
\hline $\mathrm{CD}(0.05)$ & 0.058 & & 0.041 & & 0.100 & & & 1.090 & & 0.771 & & 1.888 & & \\
\hline
\end{tabular}


Table.5 Effect of drying methods on Vigour index and Dry matter production (mg 10 seedling $^{-1}$ ) and in Sesame TMV 7

\begin{tabular}{|c|c|c|c|c|c|c|c|c|c|c|c|c|c|c|}
\hline \multicolumn{8}{|c|}{ Vigour Index } & \multicolumn{7}{|c|}{ Dry matter Production } \\
\hline Treatment & P0 & $\mathbf{P 2}$ & P4 & P6 & P8 & P10 & Mean & P0 & $\mathbf{P 2}$ & P4 & P6 & P8 & P10 & Mean \\
\hline Sun drying & 1479 & 1386 & 1295 & 1205 & 1080 & 975 & 1237 & 38.0 & 37.1 & 35.0 & 34.2 & 33.5 & 31.7 & 34.92 \\
\hline Shade drying & 1531 & 1470 & 1394 & 1327 & 1253 & 1189 & 1361 & 38.8 & 38.1 & 37.1 & 36.7 & 35.3 & 34.4 & 36.73 \\
\hline $\begin{array}{l}\text { Partial shade } \\
\text { drying }\end{array}$ & 1496 & 1436 & 1336 & 1245 & 1156 & 1064 & 1289 & 38.2 & 37.3 & 36.1 & 34.7 & 33.8 & 32.2 & 35.38 \\
\hline Mean & 1502 & 1431 & 1341 & 1259 & 1163 & 1076 & 1295 & 38.33 & 37.50 & 36.07 & 35.20 & 34.20 & 32.77 & 35.68 \\
\hline & $\mathbf{P}$ & & $\mathbf{T}$ & & PxT & & & $\mathbf{P}$ & & $\mathbf{T}$ & & PxT & & \\
\hline & 11.969 & & 8.463 & & 20.731 & & & 0.530 & & 0.374 & & 0.920 & & \\
\hline $\mathrm{CD}(0.05)$ & 23.943 & & 16.930 & & 41.470 & & & 1.062 & & 0.752 & & 1.840 & & \\
\hline
\end{tabular}

Table.6 Effect of drying methods on Electrical Conductivity $\left(\mathrm{dSm}^{-1}\right)$ and Field Emergence Percentage in Sesame TMV 7

\begin{tabular}{|c|c|c|c|c|c|c|c|c|c|c|c|c|c|c|}
\hline \multicolumn{8}{|c|}{ Electrical Conductivity $\left(\mathrm{dSm}^{-1}\right)$} & \multicolumn{7}{|c|}{ Field Emergence Percentage } \\
\hline Treatment & $\mathbf{P 0}$ & $\mathbf{P 2}$ & $\mathbf{P 4}$ & P6 & P8 & P10 & Mean & P0 & $\mathbf{P 2}$ & $\mathbf{P 4}$ & P6 & P8 & $\mathbf{P 1 0}$ & Mean \\
\hline Sun drying & 0.076 & 0.088 & 0.107 & 0.147 & 0.206 & 0.260 & 0.147 & 84 & 82 & 80 & 79 & 78 & 76 & 79.8 \\
\hline Shade drying & 0.078 & 0.085 & 0.097 & 0.141 & 0.199 & 0.254 & 0.142 & 85 & 84 & 83 & 82 & 80 & 80 & 82.3 \\
\hline $\begin{array}{l}\text { Partial shade } \\
\text { drying }\end{array}$ & 0.077 & 0.087 & 0.102 & 0.144 & 0.203 & 0.258 & 0.145 & 82 & 82 & 81 & 80 & 79 & 78 & 80.3 \\
\hline Mean & 0.077 & 0.086 & 0.102 & 0.144 & 0.203 & 0.257 & 0.145 & 83.7 & 82.7 & 81.3 & 80.3 & 79.0 & 78.0 & 80.8 \\
\hline & $\mathbf{P}$ & & $\mathbf{T}$ & & PxT & & & $\mathbf{P}$ & & $\mathbf{T}$ & & PxT & & \\
\hline & 0.060 & & 0.041 & & 0.105 & & & 0.444 & & 0.314 & & 0.770 & & \\
\hline $\mathrm{CD}(0.05)$ & 0.121 & & 0.085 & & 0.209 & & & 0.890 & & 0.630 & & 1.542 & & \\
\hline
\end{tabular}




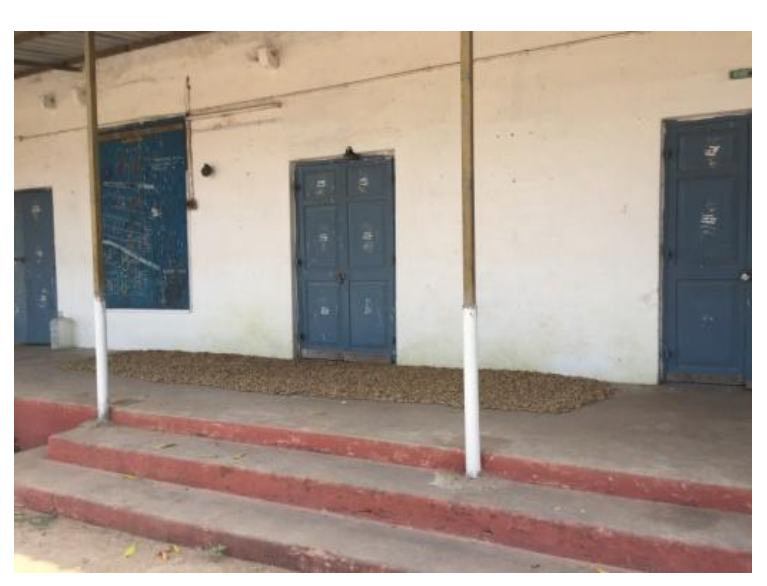

Fig.1 Shade drying
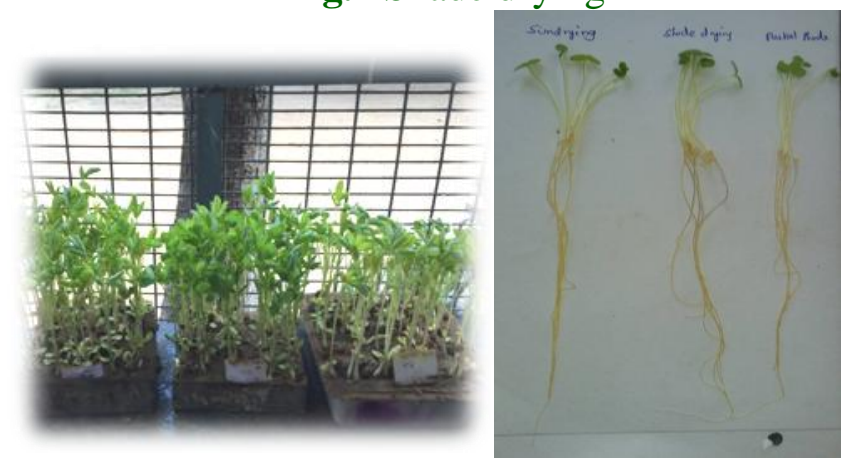

Fig.3 Seedling evaluation

This might be due to faster deterioration of cell membrane and also oxidation of polyunsaturated fatty acids in the membrane lipid compounds involving free radicle chain reaction (Srivastava, 1975).

The field emergence is the ultimate measures of seed vigour (Tonkan, 1969). In the present study, field emergence per cent also followed the same trend as that of germination per cent in respect of drying methods.

From the above study, it is concluded that the seeds dried under shade especially the rabi crop maintains the germination and other vigour parameters during its storage. The seeds of groundnut and sesame dried under shade registered highest vigour and viability upto 8 months of storage compared to other treatments under ambient condition.

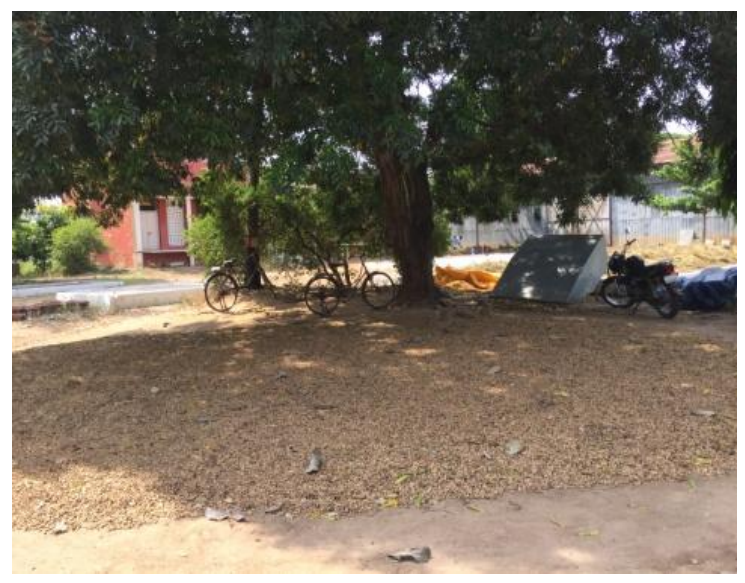

Fig.2 Partial Shade drying

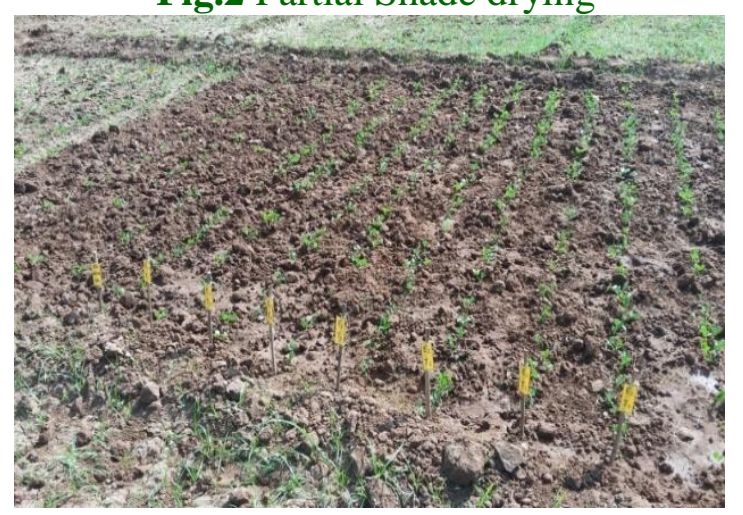

Fig.4 Field Emergence

\section{References}

Abdul-Baki, A. and Anderson, J. D.(1973). Vigour determination in soybean by multiple criteria. chemicals and containers on seed quality of marigold during storage. The Bioscan, 9: 937942. Crop. Sci., 13: 630 -633.

Ellis RH, Hong TD, Roberts EH, Tao KL (1990). Low moisture content limits to relations between seed longevity and moisture. Ann. Bot., 65:493-504.

Heydecker, W. 1972. Vigour. In:Viability of seeds (ed. E.H. Roberts), Chapman and Hall, London, pp. 209-252.

ISTA, 1999. International Rules for Seed Testing. Supplement Rules, Seed Sci. \& Technol., 27: 25-30.

Kumar, T. P.; Asha, A. M.; Maruthi, J.B. and Vishwanath, K. (2014).Influence of seed treatment 
Nakamura S (1975). The most appropriate moisture contents of seed for their long life span. Seed Sci. Tech., 3: 747-759.

Panse, V.G. and Sukhatme, P.V., Statistical Methods for Agricultural Workers, Indian Council of Agricultural Research, New Delhi, pp. 167-174 (1967).

Presley, J.T. 1958. Relationship of protoplast permeability to cotton seed viability and predisposition to seedling disease. Pl. Dis. Reporter, 42(7): 582.

Roberts, E.H. 1972. Loss of viability and crop yields. In: Viability of Seeds (ed. E.H. Roberts), Chapman and Hall Ltd., London. p.313.

Sadasivam, S. and A. Manickam. 1995. Proteins and enzymes. In:Biochemical methods for agricultural sciences, Wiley Eastern Ltd., New Delhi, pp. 33 143.

Saini, Anurag; Patel, M. B.; Patel, J. B.; Courmule, SagarR.and Mandel, Deepashree2015. Interaction effect of seed storage containers and seed treatments on seed quality in groundnut (arachis hypogea 1.) during storage. An
International e-Journal , (2015) Vol. 4, Issue 3: 228-234 ISSN 2277-9663.

Shakuntala, N.M. (2009). Influence of planting ratios, staggered planting and seed polymer coating on seed yield, quality and storability in rsfh-130 sunflower hybrid, Ph.D thesis, University of Agricultural Sciences, Dharwad.

Srivastava, A.K. 1975. Physiological studies on soybean seed viability during storage and its practical applicability. Seed Res., 4(1): 56-67.

Tonkan, J.H.B. 1969. Seedling evaluation: The use of soil tests. Proc. Intl. Seed Test. Assoc., 34: 281-289.

Vijay Kumar, Vivek Sharma and S.C. Sharma. 2014. Impact of Improved Technologies on Productivity Enhancement ofSesame (Sesamum indicum L.) Indian J. Dryland Agric. Res. \& Dev. 2014 29(2) : 41-44.

Zheng GH (1994). Ultra-dry seed storage: Possible improved strategies and technology for germplasm conservation. Chin. Biodiv., 2: 61-65.

\section{How to cite this article:}

Vijaya Geetha V. and Bhaskaran. M. 2020. Standardization of Suitable Drying Methods for Storing Groundnut and Sesame Seeds. Int.J.Curr.Microbiol.App.Sci. 9(05): 478-485. doi: https://doi.org/10.20546/ijcmas.2020.905.053 